\title{
Biosynthesis and Metabolism of Androgens
}

\author{
Kyoichiro OCHIAI and Hiroyuki OSHIMA \\ Department of Urology, Faculty of Medicine, Tokyo Medical and Dental University, Tokyo, Japan
}

Cellular elements of testicular tissue consist of three major components, namely spermatogenic cells, Sertoli cells and interstitial cells. Any definite evidences that spermatogenic cells produce androgens have not yet been obtained. Electron-microscopic studies in our laboratory revealed that interstitial cells were rich in mitochondria and endoplasmic reticulum which are indispensable for steroid hormone production, in contrast to poor development of those in Sertoli cells. Also, the activity of $3 \beta$-hydroxysteroid dehydrogenase, which biotransforms $\Delta^{5}$-3 $\beta$-hydroxysteroids to $\Delta^{4}$-3-ketosteroids is demonstrated to be localized only in interstitial cells of fetal as well as mature testes. From these facts and other many experimental findings in literature, it is reasonably concluded that testicular androgens are produced in the interstitial cell.

Enzymes related to biosynthesis of teststerone from pregnenolone are $3 \beta$-hydroxysteroid dehydrogenase ( $3 \beta$-DHG), 17 $\alpha$-hydroxylase (17 $\alpha$-OHase), $17 \alpha$-hydroxypregnene $\mathrm{C}_{17}-\mathrm{C}_{20}$ lyase $\left(\mathrm{C}_{17}-\mathrm{C}_{20}\right.$ lyase) and $17 \beta$-hydroxysteroid dehydrogenase (17 $\beta$-DHG). These enzymes are demonstrated to be localized in microsomal fraction, when the homogenate of testicular tissue is divided into subcellular fractions by conventional differential centrifugation, and require NADPH as cofactor except $3 \beta-\mathrm{DHG}$, which requires $\mathrm{NAD}^{+}$as hydrogen receptor. When testicular microsomes of aged men (five cases) were incubated with pregnenolone $-4-{ }^{14} \mathrm{C}$, no metabolites other than $\Delta^{4}$-3-ketosteroids were obtained, while $3 \beta$-DHG showed low activity and others above described were highly active (particulars will be published elswhere). From these results, in vitro biosynthetic pathway of of androgens in human testes is considered as follows ; pregnenolone $\rightarrow$ progesterone $\rightarrow 17 \alpha$ hydroxyprogesterone $\rightarrow \Delta^{4}$-androstenedione $\rightarrow$ testosterone. This metabolic pathway is also ascertained in the same experiment with homogenates of mature rat testes.

There are some other enzymes related to androgen bioconversion in testes. 1) $20 \alpha$ Hydroxysteroid dehydrogenase in human testes converts progesterone to $20 \alpha$-hydroxypregn-4-en-3-one and 17 $\alpha$-hydroxyprogesterone to 17 $\alpha$-, 20 $\alpha$-dihydroxypregn-4-en-3-one, which inhibits the activity of $\mathrm{C}_{17}-\mathrm{C}_{20}$ lyase and furthermore, is unsuitable for $\mathrm{C}_{17}-\mathrm{C}_{20}$ lyase. 2) $16 \alpha$-Hydroxylase shows substrate specificity for progesterone, but the meaning in testes remains unexplained. 3) $\Delta^{4}-5 \alpha$-reductase and $3 \alpha$-hydroxysteroid dehydrogenase are highly active in testes of immature and hexestrol-treated rats. As a result of high activities of these enzymes, $5 \alpha$-saturated and $3 \alpha$-hydroxylated steroids are mainly produced in these testes in vitro.

When male animals were treated with androgens or estrogens, androgen production 
in testes is lowered by feed-back mechanism. By incubation studies of animal and human testicular tissue with appropriate precursor steroids, it was found that $17 \alpha$ OHase, $\mathrm{C}_{17}-\mathrm{C}_{20}$ lyase, $17 \beta$-DHG and $16 \alpha$-OHase were significantly inhibited by the treatment, whereas $3 \beta-D H G$ was not affected. Human testes were affected by hexestrol administration as above stated. But, in rat testes treated with large doses of hexestrol, peculier changes of steroidal metabolic pathway were observed : Enzyme activities related to androgen biosynthesis were inhibited and $4^{4}-5 \alpha$-reductase and $3 \alpha$-hydroxysteroid dehydrogenase were significantly activated. The results suggest the direct effect of exogenous synthetic estrogen upon testes.

Androgen biosynthesis in vitro was proved in human adrenals. $17 \alpha$-OHase in human adrenals is highly active, but $\mathrm{C}_{17}-\mathrm{C}_{20}$ lyase and $17 \beta$-DHG are poorly active, resulting in low conversion of $\mathrm{C}_{21}$ to $\mathrm{C}_{19}$ steroids and high value of $\Delta^{4}$-androstedione/testosterone ratio.

The produced androgens are mainly metabolized in liver and kidney is known to metabolize steroids. But there are only hydroxysteroid dehydrogenase and glucuronyl transferase, and activities of $5 \alpha$ - and $5 \beta$-reductase, and $\Delta^{4}-\Delta^{5}$ isomerase are not demonstrated in human kidney. Considering the results above described, human kidney is thought not to be the main organ for steroid metabolism.

(pp. 851 857) 


\title{
シンポジゥム $\quad$ III $\quad$ 性ホルモンの代謝
}

\section{3. 辠丸性 androgens の生成と変換}

（附：ヒト副腎における androgens の生成）

\author{
東京医科歯科大学泌尿器科教室 \\ 落 合 京一 郎, 大 島 博 幸
}

\section{（I）睪丸における testosterone の生合成}

生体でつくられる androgens のうち, testosterone が最も重要なもので, 辡丸がその主たる生成部位で あるてとは，いろいろな実験から確かといつてよい．ての testosterone が等丸のどの部分で，ぞのような前 駆物質からどのような経路あるいは過程でつくられるか，てれについては最近における実験方法の長足な進 歩によつて漸次明らかにされつつある。

\section{(a) 睪丸における testosterone 生合成の部位}

てれはいろいろなデータから Leydig 細胞と考えてよい,われわれはヒト睪丸の Leydig 細胞につき詳 しい光顕的, 電顕的検索を行なつたが, 成熟型のものの電顕所見は均等の大きさの滑面小胞体が ectoplasm に多数に存在, Golgi 体もよく発達しているが, RNA は比較的少ないのが特有で, てれは活動型の副腎皮 質細胞のそれと全く酷似している (Hatakeyama，S.：Acta Path，Jap., 15，155，1965)。しかし，Sertoli 細 胞の電顕的所見は極めて単純な構造を示しており，少なくともステロイド分泌能の存在は考えられない。ま た, 胎児から考人に至る年令屏の辠丸について各種の酵素活性を組織化学的に検索したが，とくにステロイ ド代謝に関係の深い $3 \beta$-hydroxysteroid dehydrogenase ( $\beta \beta$-Ol DHG, Allen 染色法) の活性は Leydig 細胞のみに証明され，その活性度は睪丸の androgens 分泌能の消長とよく一致している (Sengoku, K. :

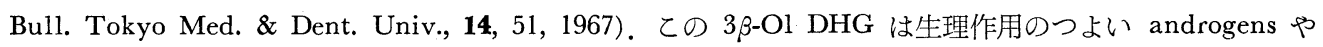
皮質ホルモンに共通した $\Delta^{4}$-3-keto 体という key compound の生成に重要な醉素で，ての所見は辠丸にお ける testosterone 生成が Leydig 細胞内で行なわれているととの1つの傍証と見るてとができる.

(b) 睪丸における testosterone 生合成の経路亡酵素系

殬丸の homogenate は分別遠沈法によつてミトコンドリア, ミクロゾームおよび可溶性分画に分けるて とができる (Tamaoki \& Shikita: Steroids Dynamics, ed. Pincus, Acad. Press, 1966). てのようにして 得られた各分画について, ${ }^{14} \mathrm{C}$ でラベルした pregnenolone, progesterone, $17 \alpha$-OH-progesterone, $\Delta^{4}$-androstenedione などをそれぞれ基質として incubate し，その生成物を分離同定したのち定量した．てれらの 成績をもとに，辡丸における androgens の生成や変換を追求するとともに，てれに参与する醉素群の種類， 細胞内の分布などを検索した．まず cholesterol から pregnenolone への変換にはたらくものとして cholesterol-10 $\alpha$-hydroxylase, 22R-hydroxylase, $\mathrm{C}_{20}-\mathrm{C}_{22}$ lyase などがあり，てれらはいずれもミトコンドリア 分画に存在する. pregnenolone から testosteroneが合成されるのに必要な醳素としては $\beta$-hydroxysteroid dehydrogenase ( $3 \beta$-Ol DHG), $\Delta^{5}$ - $4^{4}$-isomerase, $17 \alpha$-hydroxylase, $\mathrm{C}_{17}-\mathrm{C}_{20}$ lyase, $17 \beta$-hydroxysteroid dehydrogenase (17 $\beta-\mathrm{O} \mathrm{DHG})$ などがあり，てれらはミクロゾーム分画に存在する(これら酵素の細胞内分 布はマウス,ラット，サルのみならずヒトでも共通).

すでにラット䅸丸の in vitro 実験からは, pregnenolone $\rightarrow$ progesterone $\rightarrow 17 \alpha$-OH-progesterone $\rightarrow \Delta^{4}-$ andrstenoedione $\rightarrow$ testosterone という主たる生合成経路が考えられる (Shikita et al. : Steroids， 4，521， 
Table 1 In vitro biosynthesis of testosterone in human testis $\left({ }^{14} \mathrm{C}\right.$-Pregnenolone $10 \mu \mathrm{g}$, microsomal fractions of testis) $\%$ conversion of substrate

\begin{tabular}{c|c|c|c|c|c|c|c}
\hline Age & Preg. & Prog. & $\begin{array}{c}17 \alpha \text {-OH- } \\
\text { Prog. }\end{array}$ & A-dione & T. & $\begin{array}{c}17 \alpha-\mathrm{OH}- \\
\text { Preg. }\end{array}$ & DHA \\
\hline \hline 56 & 85.6 & 1.3 & 0.4 & 1.0 & 0.8 & $\mathrm{n} . \mathrm{g}$. & $\mathrm{n} . \mathrm{g}$. \\
59 & 89.4 & 3.1 & 0.6 & 0.6 & 1.4 & $\mathrm{n} . \mathrm{g}$. & $\mathrm{n} . \mathrm{g}$. \\
68 & 90.9 & 1.3 & 0.3 & 0.4 & 0.7 & $\mathrm{n} . \mathrm{g}$. & $\mathrm{n} . \mathrm{g}$. \\
69 & 96.1 & 0.6 & 0.4 & 0.5 & 0.7 & $\mathrm{n} . \mathrm{g}$. & $\mathrm{n} . \mathrm{g}$. \\
71 & 77.9 & 0.6 & 0.5 & 0.4 & 0.6 & $\mathrm{n} . \mathrm{g}$. & $\mathrm{n} . \mathrm{g}$. \\
\hline
\end{tabular}

n.g. : negligible

(Oshima, 1968)

1964)。5 例のヒト箤丸について ${ }^{14} \mathrm{C}$-pregnenolone を基質としたわれわれの in vitro 実験でも，ラットと 同じ生合成経路が証明され，17-OH-pregnenolone や DHEA は negligible にしか得られなかつた（大島： 実験法については王置，大島などの原著を参照, Table 1). In vitro 実験でもサルでは pregnenolone $\rightarrow 17 \alpha-$ $\mathrm{OH}$-pregnenolone $\rightarrow \mathrm{DHEA} \rightarrow \Delta^{4}$-androstenedione $\rightarrow$ t. が主経路だという報告もあり (Hoschoian \& Brownie : Steroids, 10,49，1967)，in vivo 実験でもとの経路が主だという発表 (Lucis et al. : Canad. J. Biochem., 45，1213，1967 など)，あるいは $\Delta^{5}$-androstenediol $\rightarrow$ t. という経路の存在も指摘されている。睪丸における $\mathrm{t}$ ．生合成経路が in vivo ではどれが主としてはたらいているか，またてれには種属によるちがいがある のかどうか未定であるが，われわれの実験ではヒトもラットも同じ生合成経路と考えてよい. おそらく $\Delta^{5}$ $\Delta^{4}$-isomerase がどてにはたらくかなどにもよると考えられるが，少なくとも辠丸には上述のどの経路も存在 するとみてよい.

なお，このヒト睪丸の実験では pregnenolone $\rightarrow$ progesterone への変化が弱いが，乙れは年長者の睪丸だ からと考えられるもので， ${ }^{14} \mathrm{G}$-progesterone を基質とした実験では $\mathrm{t}$ 。への変化はかなり円滑に進行するこ とを認めている (大島)。 そこでさらに, ${ }^{14} \mathrm{C}$ でラベルした pregnenolone, progesterone, 17-OH-progesterone, $\Delta^{4}$-androstenedione をそれぞれ基質して incubate し，各酵素の活性をしらべた（Table 2)。乙れに

Table 2. Enzyme Activities Related to Androgen Biosynthesis in Human Testis.

\begin{tabular}{c|c|c|c|c|c}
\hline \hline Age & $\begin{array}{c}3 \beta-\mathrm{ol} \\
\text { DHG }\end{array}$ & $\begin{array}{c}17 \alpha- \\
\text { Hydroxylase }\end{array}$ & $\begin{array}{c}\mathrm{C}_{17}-\mathrm{C}_{20} \\
\text { lyase }\end{array}$ & $\begin{array}{c}17 \beta \text {-ol } \\
\text { DHG }\end{array}$ & $\begin{array}{c}\text { Urinary } \\
\text { G. }\end{array}$ \\
\hline \hline 56 & $17.7 *$ & 287.5 & 96.1 & 441.7 & $6^{* *}$ \\
59 & 34.8 & 204.9 & 154.1 & 525.8 & 6 \\
68 & 26.7 & 191.7 & 91.7 & 210.6 & 24 \\
69 & 8.8 & 136.6 & 62.1 & 364.4 & 24 \\
71 & 6.1 & 87.2 & 20.4 & 278.8 & 12 \\
\hline
\end{tabular}

$* 10^{-5} \mu$ moles of the products/mg of protein

**m.u.u./day

(Oshima, 1968)

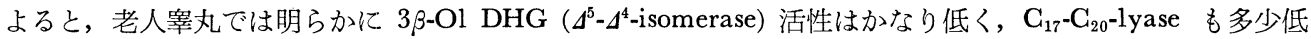
下を示しており，乙の後者については $20 \alpha-\mathrm{Ol}$ DHG という酵素の関与も推定される (後述). $3 \beta-O 1$ DHG の活性低下と尿の gonadotropin 排泄值との間にははつきりした相関関係は認められなかつた (Table 2). ラットの未熟な睪丸では $3 \beta-\mathrm{O} 1 \mathrm{DHG}$ と $17 \beta-\mathrm{O} 1 \mathrm{DHG}$ の活性が弱いが，前者は $\mathrm{g}$.の投与によつて著明 に活性化される。ところが，未熟睪丸ではこのほか，特有な代謝経路の存在が証明されている（Inano＆ Tamaoki : Endocrinol., 79, 579，1966)。すなわち，17-OH-progesterone や $\Delta^{4}$-androstenedione のところ で，正常な $\mathrm{t}$ ，生合成経路からはずれた代謝が活発にはたらいており， t 。 にならずに androsterone p 
epiandrosterone となつてしまう。ごく少量はt。になるが，すぐ dihydroxytestosterone を経て androsterone などに代謝されてしまう。こてで主としてはたらいているのは $\Delta^{4}-5 \alpha$-reductase であるが，ラットの 未熟鋅丸内においてもすでに一種の代謝変換の行なわれているてとは興味がある。しかし，ヒトの未熟昱丸 でも同じかどうかは未定である.

\section{（II）睪丸における androgens の変換と酵素群}

上述の $\Delta^{4}-5 \alpha$-reductase もその一つであるが， androgens の辠丸内変換に参与する酵素には次のものなど がある.

(a) 20a-hydroxysteroid dehydrogenase : ラット笡丸の可溶性分画には $17 \alpha-\mathrm{OH}$-progesterone を特 異的に基質とする酵素が存在，NADPH の存在で 17 $\alpha$, 20 $\alpha$-dihydroxy-pregn-4-en-3-one をつくる. とて ろが，ミクロゾーム分画に存在する $\mathrm{C}_{17}-\mathrm{C}_{20}$ lyase は共通の基質 $17 \alpha$-OH-progesterone にはたらいてその 側鎖を切断するが，乙れは条件のちがいによるてとが明らかにされている (Inano et al. : BBA，137，540， 1967)，好気的および嬚気的条件下で 17-OH-progesterone を基質としてラット殬丸 homogenate を incubate した生成物をしらべると，嫌気下では $\mathrm{C}_{17}-\mathrm{C}_{20}$-lyase 活性は低下し $20 \alpha-\mathrm{O} 1 \mathrm{DHG}$ 活性が強くはたらい て 17 $\alpha, 20 \alpha$-dihydroxy 体の生成が著明に增加している. 次に ${ }^{3} \mathrm{H}-17 \alpha-\mathrm{OH}$-progesterone ${ }^{14} \mathrm{C}-17 \alpha, 20 \alpha-$ dihydroxy 体をつかつて $\mathrm{C}_{17}-\mathrm{C}_{20}$ lyase 活性への作用を検索すると，ての dihydroxy 体は $\mathrm{C}_{17}-\mathrm{C}_{20}$ lyase に拮抗的（抑制的）にはたらくことが確められた。 ヒト等丸でもこの $17 \alpha, 20 \alpha$-dihydroxy 体が比較的多く 生成されるが，乙れでは基質として progesterone と 17-OH-progesterone の両方が利用され，好気的条件 下でも嫝気下ほどではないがての酵素ははたらいている(大島，Table 3)。またての酥素活性は estrogens 投 与によつてもほとんど抑制をうけない（大島，Table 4)。乙のヒト実験で dihydroxy 体が多く生成される のは材料が老人鋅丸からかも知れないが，次の可能性を示しているともいえる。たとえば睪丸動脈の老人性

Table 3. Metabolism of progesterone in vitro by homogenates of human testis (\% Conversion of Substrate)

\begin{tabular}{c|c|c|c|c|c}
\hline Age & $\begin{array}{c}17 \alpha-\mathrm{OH}- \\
\text { Prog. }\end{array}$ & A-dione & $\mathrm{T}$ & $\begin{array}{c}20 \alpha-\mathrm{OH}- \\
\text { p-3-one }\end{array}$ & $\begin{array}{c}16 \alpha-\mathrm{OH}- \\
\text { Prog. }\end{array}$ \\
\hline \hline 56 & 25.8 & 1.0 & 2.4 & 6.8 & 15.4 \\
59 & 4.3 & 0.3 & 13.4 & 31.1 & 22.4 \\
68 & 20.5 & 0.3 & 3.7 & 11.0 & 11.8 \\
69 & 39.6 & 0.6 & 9.0 & 23.4 & 12.5 \\
71 & 31.3 & 0.5 & 1.7 & 3.0 & 13.0 \\
\hline
\end{tabular}

(aerobic condition)

(Oshima, 1968)

Table 4. 20 $\alpha$-Hydroxysteroid dehydrogenase activity in soluble fractions of human testis $\left(10^{-5} \mu\right.$ moles of metablite $/ \mathrm{mg}$ of protein $)$

\begin{tabular}{c|c|c|c|c}
\hline \hline \multirow{2}{*}{$\begin{array}{c}\text { Substrate } \\
\text { used }\end{array}$} & \multicolumn{2}{|c|}{ Progesterone } & \multicolumn{2}{|c}{$17 \alpha$-OH-Prog. } \\
\cline { 2 - 5 } & Control & $\begin{array}{c}\text { with } \\
\text { Hexestrol }\end{array}$ & Control & $\begin{array}{c}\text { with } \\
\text { Hexestrol }\end{array}$ \\
\hline \hline 58 yrs. & - & - & 21.3 & 18.8 \\
59 yrs. & - & - & 21.9 & 22.5 \\
68 yrs. & - & - & 47.2 & 43.5 \\
69 yrs. & 40.2 & 36.5 & 21.2 & 28.6 \\
\hline
\end{tabular}

(anaerobic condition)

(Oshima, 1968) 
変化により $\mathrm{O}_{2}$ 供給不足が生じており，乙の条件下では $20 \alpha-\mathrm{O}$ DHG がより強くはたらいて dihydroxy 体 が多く生成されるため $\mathrm{C}_{17}-\mathrm{C}_{20}$ lyase 活性は低下する。一方, ての dihydroxy 体は 17-OH-progesterone に逆変化し得るという報告もあり (Dominguez：Steroid, 7, 433，1966), dihydroxy 体が多くつくられてプ 一ルされておれば，乙れが動員されて不足した $17 \alpha-\mathrm{OH}$-progesterone を補給する機構，つまり条件に応じ て鋅丸内でも androgen の代謝に一種の調節が行なわれるということが想定される。いずれにしろ，てのよ うに 2 種類の酵素が共通の基質をとりとんで，それぞれちがつた生成物をつくる経路を進行させ得るという 現象は極めて興味深い，どちらの方向の代謝経路をとるか，それを決定する条件とか原因の追求は，箤丸に おけるステロイド合成代謝の動態を知るのに重要な手がかりにもなるからである.

(b) $\Delta^{4}$-5a-reductase : ラットの未熟睪丸における特有な androgens 代謝にも関与しているが，ての醳 素は成熟ラットへの estrogens 投与によつても活性か強められる。合成発情物質の投与によつて辠丸の $\mathrm{t}$. 生合成は抑制されるが (Oshima et al.：BBA，137，356，1967)，乙のほか異化方向ともいうべき別の代謝経 路が促進される (Fig. 1)。すなおち progesterone から $5 \alpha$-pregnan-3,20-dione $\rightarrow 3 \alpha$-hydroxy- $5 \alpha$-pregnan-

Fig. 1 Exogenous estrogen upon androgen biosynthesis
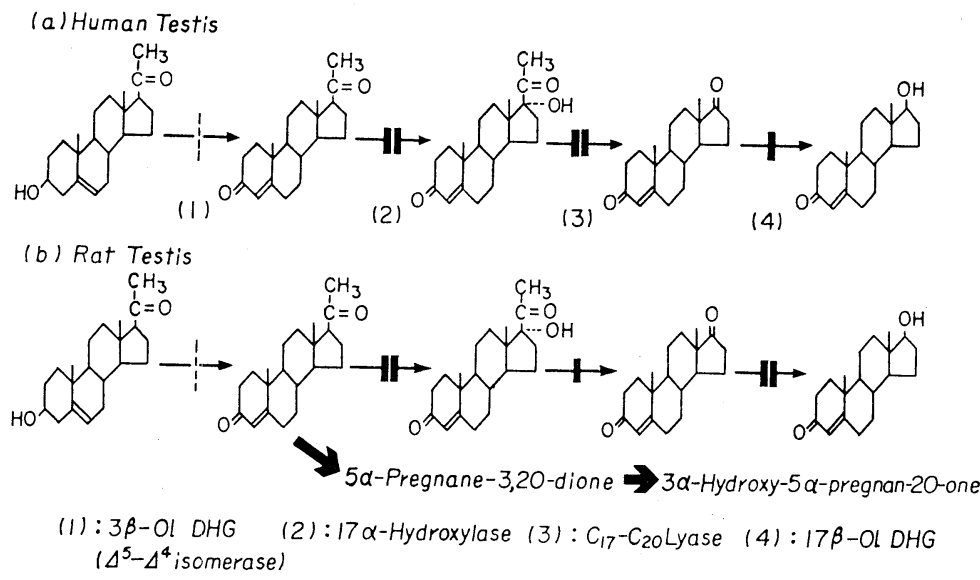

20-one というホルモン作用のないステロイド生成への異化が生ずる。この方向を決定づける因子は estrogens である。しかし，ヒト辠丸では estrogens 投与によるこの異化経路の発現は確認されなかつたが（大島， Fig. 1 参照)，乙れは種属のちがいか投与量も関係しているのかも知れない，なお，ラットではての $\Delta^{4}-5 \alpha-$ reductase は基質として 17 $\alpha$-OH-progesterone, androstenedione, t. をも利用できる (Inano\& Tamaoki： Endocrnol., 79, 579, 1966).

(c) 16 $\alpha$-hydroxylase : 乙の酵素は副腎, 卵巢, 胎盤や肝などに存在し，とくに副腎では活性が高い. ヒ卜睪丸にもこの $16 \alpha$-hydroxylase が存在し (ミクロゾーム分画), その活性はかなり高く progesterone そのものの10〜20\%はこれによる代謝をうけている(Oshima et al. : J. Clin. Endocrinol., 27, 1249, 1967). 基質特異性の検索では， progesterone だけから有意の差で $16 \alpha$-OH-progesterone が収量されており，progesterone 亿特異性をもつと考えられる，20 $\alpha$-Ol DHG とちがい， estrogens 投与によつて強く抑制される (Table 4)。ただ現在のとてろ，16 $\alpha$-hydroxylase が睪丸における androgens の代謝にどのような役割りを もつているかはまだはつきりしない.

\section{（III） 外因性ホルモンの睪丸の androgens 合成への影響}

（a）外因性 estrogens : ラット浒丸では estrogens 投与によつて前葉の LH 合成能抑制と酵素活性の抑 第44巻 第 8 号 
制のほか，特異の異化方向への代謝が促進されて結局は $\mathrm{t}$ ，生合成は減少するが，ヒトではての異化経路は 確認できず，また醭素活性の抑制パターンも多少ちがつている．4例のヒトにおいて estrogens 投与前後に 片側ずつ剔出した鋅丸について，各醉素活性を検索比較した成績によると，3 $\beta$-O1 DHG はあまり抑制され ないが，17 $\alpha$-hydroxylase は最も強く $\mathrm{C}_{17}-\mathrm{C}_{20}$ lyase もかなり強く抑制されるが，17 $\beta$-Ol DHG はわりあ いに抵抗力強い（大島，Fig. 1).

(b) 外因性 androgens : ラット辡丸ではある量以上の androgens 投与によつても明らかに $\mathrm{t}$. 生合成 は抑制されるが， estrogens とちがい異化方向への代謝路の促進は認められなかつた（Oshima： Endocr. Jap., 14, 75, 1967)。各醳素群の抑制も estrogens 投与のパターンと本質的に異なるとてろはないといえる が，てれでは $17 \alpha$-hydroxylase と $17 \beta$-Ol DHG，とくに前者の活性が著明に抑えられ，投与中止後の恢復 は後者が最もおそい.

外因性の androgens や estrogens 投与によつて前葉の LH 合成能が抑えられる feed-back 機序は動物 実験で確められている (anti-LH-NIH-S 8 で分離した LH 分画への ${ }^{14}$ C-leucine のとり込み実験, Wakabayashi \& Tamaoki : Endocrinol., 79, 477, 1966 ; Oshima et al. : BBA, 137, 356, 1967). しかし, gonadotropin が cholesterol あるいは pregnenolone から t 。への生合成経路のどのリンクに主として作用して いるか，ての点はまだ完全には判つていない，上述した一連の実験成績から考えると，少なくとも未熟睪丸 ではこれによつて $3 \beta-O 1$ DHG が活発化されること, 一たん成熟した箤丸では $3 \beta-O 1$ DHG はわりあい反 応性が強くないとと, そのほかの酵素も gonadotropin 反応性に差があると考えられるが，むしろある量以 上の estrogens あるいは androgens は直接に酵素活性にはたらく可能性も推定される.

\section{（IV）ヒト副腎皮質における androgens の生成}

2 例の先天性副腎過形成 (congenital adrenal hyperplasia), 2 例の Cushing 症候群 (過形成, 腺腫各 1 例), estrogens 長期大量投与の前立腺癌 1 例の剔出副腎につきステロイド生成を incubation 実験を行な い, 対照例（41才男，高血圧）のそれと比較検索した（詳細は近く峌田が原著として発表の予定, Table 5, Table 6). (i) CAH では 17 $\alpha$-OH-progesterone の生成は増加しているが，皮質ホルモン (corticosterone, cortisol）は生成されず, DOC も negligible であるのに対し $\Delta^{4}$-androstertdione, t. は年令に比してかな

Table 5. Bioconversion of progesterone $-{ }^{14} \mathrm{C}$ by human adrenal homogenates

\begin{tabular}{|c|c|c|c|c|c|c|c|}
\hline Disease Age, Sex & $\begin{array}{c}\text { Control } \\
41 \mathrm{~m}\end{array}$ & $\begin{array}{l}\text { CAH } \\
14 \mathrm{f} \\
\end{array}$ & $\begin{array}{c}\text { CAH } \\
4 \mathrm{f} \\
\end{array}$ & $\begin{array}{c}\text { Cushing } \\
15 \mathrm{f}\end{array}$ & $\begin{array}{l}\text { Cushing* } \\
28 \mathrm{f}\end{array}$ & \begin{tabular}{|c|} 
Gushing* \\
$28 \mathrm{f}(\mathrm{ad})$
\end{tabular} & \begin{tabular}{|l} 
E. treated \\
$57 \mathrm{~m}$
\end{tabular} \\
\hline $\begin{array}{l}\text { Progesterone } \\
\text { (recovered) }\end{array}$ & $17.4^{* *}$ & 2.3 & 17.7 & 4.9 & 4.1 & 8.3 & 8.8 \\
\hline $17 \alpha-\mathrm{OH}-\mathrm{Prog}$. & 17.5 & 23.8 & 25.9 & 17.4 & 22.6 & 24.5 & 17.0 \\
\hline 11-Deoxycortisol & 3.7 & $\mathrm{n} . \mathrm{d}$. & $\mathrm{n} . \mathrm{d}$. & 6.7 & 8.9 & 7.7 & 14.6 \\
\hline Cortisol & 1.0 & $\mathrm{n} . \mathrm{d}$. & n.d. & 0.4 & 0.8 & 0.6 & 4.2 \\
\hline DOG & $\mathrm{n} . \mathrm{g}$ & $\mathrm{n} . \mathrm{g}$. & $\mathrm{n} . \mathrm{g}$. & 2.3 & 1.5 & 1.4 & $\mathrm{n} . \mathrm{g}$. \\
\hline Gorticosterone & 2.6 & $\mathrm{n} . \mathrm{d}$. & $\mathrm{n} . \mathrm{d}$. & 1.2 & 2.5 & 2.1 & 7.5 \\
\hline$\Delta^{4}$-A-dione & 1.5 & 3.9 & 1.0 & 0.9 & 0.7 & 0.3 & 1.1 \\
\hline Testosterone & 1.0 & 0.5 & 0.6 & 0.6 & 0.3 & 0.6 & 0.5 \\
\hline $16 \alpha-\mathrm{OH}-\mathrm{Prog}$. & 9.2 & 15.1 & 11.3 & 0.8 & 15.3 & 14.3 & 9.5 \\
\hline $17 \alpha, 20 \alpha$-Diol-p-3-one & 3.6 & 9.9 & 4.4 & 1.0 & 0.5 & 0.4 & 2.3 \\
\hline $17 \alpha, 20 \beta$-Diol-p-3-on 1 & $\mathrm{n} . \mathrm{g}$. & 6.3 & 1.3 & n. g. & n. g. & $\mathrm{n} . \mathrm{g}$. & $\mathrm{n} . \mathrm{g}$. \\
\hline $\begin{array}{l}\text { Not identified } \\
\text { Products }\end{array}$ & 4.9 & 4.3 & 3.1 & $\mathrm{n} . \mathrm{g}$. & 1.7 & 1.9 & 3.9 \\
\hline
\end{tabular}

n.g. ; negligible, n.d. ; not detected

(Sarada, 1968)

$* * 10^{-2} \mu$ moles of the product/gm tissue * Same patient 
Table 6. Enzyme activities related to steroid biosynthesis in adrenal

\begin{tabular}{l|c|c|c|c|c|c|c|c}
\hline \hline & Control & CAH & CAH & Cushing & Gushing** & $\begin{array}{c}\text { Cushing** } \\
\text { (adonoma) }\end{array}$ & E. treated \\
\hline $\begin{array}{c}21 \text {-Hydroxylated } \\
\text { Products* }\end{array}$ & 7.2 & - & - & 10.6 & 13.7 & 11.8 & 26.3 \\
$\begin{array}{c}17 \alpha \text {-Hydroxylated } \\
\text { Products* }\end{array}$ & 28.3 & 44.4 & 33.2 & 27.0 & 33.8 & 34.2 & 39.7 \\
$\begin{array}{c}11 \beta \text {-Hydroxylated } \\
\text { Products }\end{array}$ & $5.3^{* *}$ & $2.6^{* *}$ & $2.7^{* *}$ & $5.5^{* *}$ & $8.2^{* * *}$ & $7.0^{* * *}$ & $26.2^{* *}$ \\
\hline
\end{tabular}

* Progesterone as substrate

** DOG as substrate

***11-Deoxycortisol as substrate

** Same patient $\left(10^{-2} \mu\right.$ moles of products/gm tissue)

(Sarada, 1968)

り多量に生成されている. (ii) Cushing では 17 $\alpha$-OH-progesterone はやや増加しているほか, $11 \beta$-deoxycortisol および DOG ははつきり増加を示しているが, androgens 生成には有意の増強は認められない。 なお，28才女の第 2 例は過形成の部分と腺腫について検索したが両者の間にはステロイド生成にちがいは確 認できなかつた. (iii) estrogens 投与例では $11 \beta$-deoxycortisol, corticosterone のみならず cortisol の生成 增強を認めたが androgens 生成はあまり変化を認めない.さらに ${ }^{14} \mathrm{C}$ でラベルした DOC および $11 \beta-$ deoxycortisol をも基質として各酵素群の活性を検索した (Table 6). (i) CAH では 21-hydroxylase 活性 は認められず $11 \beta$-hydroxylase 活性も低下を示している. (ii) Cushing および estrogens 投与例では $17 \alpha$ のみならず21-および $11 \beta$-hydroxylase のいずれの活性も増強を示している. なお, ${ }^{14} \mathrm{G}$-pregnenolone を 基質とした in vitro 実験をも併施したが，17 $\alpha$-OH-pregnenolone および DHA は negligible 程度にし か得られなかつた，てれは実験方法にもよるためと考えられるが，少なくともヒト副腎の in vitro 実験で は pregnenolone $\rightarrow$ progesterone $\rightarrow 17 \alpha-\mathrm{OH}$-progesterone $\rightarrow$ とう合成経路もはたらいていると考えてよい.

\section{（V）ヒト腎における androgens の代謝}

腎における androgens の代謝に関してはまたあまり検索されていない.われわれはヒト腎の homogenate について， $\Delta^{4}$-3-keto の還元，17 $\beta-\mathrm{OH}$ の酸化，抱合体の生成などに重点をおいた異化代謝を実験した (詳細は大島が発表予定)。 ${ }^{14} \mathrm{C}$ でラベルした progesterone, DHA および $\Delta^{4}$-androstenedione を基質とし， 腎皮質および髄質について検索比較した。 その結果， progesterone から 20 $\alpha$-hydroxy-pregn-4-en-3-one, DHA から androst-5-ene-3 $\beta, 17 \beta$-diol， $\Delta^{4}$-androstenedione からわずかながら $\mathrm{t}$ 。の生成を認めた。皮質 と髄質とでは有意の差はない. $\Delta^{4}-5 \alpha$-reductase 活性は証明せず，ただ ${ }^{14} \mathrm{C}-\mathrm{DHA}$ を基質としたものでは $\Delta^{5}$-androstenediol のほかに，別の生成物が分離されたが， $\mathrm{CrO}_{3}$ で酸化されず，無水酢酸でアセチル化さ れず， $\beta$-グルクロニダーゼで遊離の DHA が得られ， solvolysis では不変なととから sulfate 抱合体で

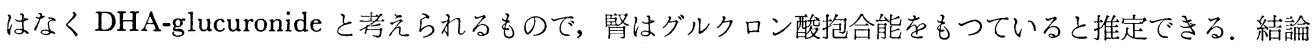
は保留するが，以上の成績から腎は androgens の代謝，とくに異化代謝の主たる藏器とは考えられない.

本研究に協力された放射線総合医学研究所の玉檤, 色田, 若林, 稲野, 中野博士に深謝する.

質問：京府医大 吉田 秀雄, 性ホルモンの作用は生殖作用と第二次性徽であると思うが, 種属保存の 立場は除外して，一方老人になると性ホルモンの衰退が来る。老人の固体保存の立場から性ホルモンの使用 が良いのか，悪いのか，無関係なのか男性を対象としてお教え願いたい.

応

答 : 東京医歯大 落合京一郎 
男性に対する androgen，とくに testosterone の投与の適応はその不足への補給というのが本筋である. 老人で屯莘丸性男性ホルモンの分泌低下があり, 当然補給療法の適応症の一つといえないととはないが, 老 化という現象が性ホルモン不足を主因とするものとは考えられないので, 老化の進行遅延あいいは恢復を目 的としての投与は本筋とはいえない.

成績の解釈については in vitro 実験という一つの制限を考えねばならない，われわれもとの data から 得られたあるステロイドの合成代謝経路が in vivoでも主たるものとは考えておらず，ただそのような経路 あ存在するというととを示したあのである，自律神経の関与の点は十分考慮すべきとてろであるが，現在わ れわれはこれに関する成績をむち合わせていない。ただての関連はむしろ副腎における皮質および髅質との 関係などがまず手がかりになるかも知れない. 